\title{
In vitro Assessment of Biofield Energy Treated DMEM on Thermogenesis Using Myoblasts Cell Line (C2C12)
}

\author{
Dahryn Trivedi ${ }^{1}$ and Snehasis Jana ${ }^{2 *}$ \\ ${ }^{1}$ Trivedi Global, Henderson, USA \\ ${ }^{2}$ Trivedi Science Research Laboratory Pvt. Ltd., Bhopal, India
}

Submission: October 26, 2018; Published: November 14, 2018

*Corresponding author: Snehasis Jana, Trivedi Science Research Laboratory Pvt. Ltd., Bhopal- 462026, Madhya Pradesh, India

\begin{abstract}
Mitochondrial dysfunction lead to various serious disorders, which are considered as one of the important components related with the aging, such as type-2 diabetes and Alzheimer's disease. The aim of the present study was to examine the effect of Consciousness Energy Healing based DMEM medium on murine myoblasts (C2C12) cells to evaluate the mitochondrial mass content using 10-N-nonyl acridine orange (NAO) dye assay. The test item (DMEM medium) was divided into two parts, one part received Consciousness Energy Healing Treatment by a renowned Biofield Energy Healer, Dahryn Trivedi and was labeled as the Biofield Energy Treated DMEM group, while the other part did not receive any kind of Treatment and denoted as the untreated DMEM group. The level of mitochondrial mass content was assessed using 10-N-nonyl acridine orange (NAO) dye method. Cell viability of the test items using MTT assay showed $72.32 \%$ and $125.32 \%$ viable cells in the untreated DMEM and Biofield Energy Treated DMEM groups, respectively suggested a safe and nontoxic profile of the test items. Besides, the mitochondrial mass content in terms of Fluorescence Unit (FU) was significantly $(p \leq 0.05)$ increased by $81.78 \%$ in the Biofield Energy Treated DMEM group compared to the untreated DMEM group. Overall, the experimental data suggested that the Consciousness Energy Healing Based DMEM showed a significant improvement of mitochondrial mass content and results in better thermogenesis with respect to naive DMEM. Thus, an increased level of NAO dye accumulation in muscle cells indicated increased mitochondrial mass content and hence, better thermogenesis. In the present study, results demonstrated that an increased mitochondrial mass content in the cells when treated with The Trivedi Effect ${ }^{\circledR}$. This indicates that the test sample has the potential to improve thermogenesis, which can be used against various metabolic diseases, such as insulin resistance, type- 2 diabetes, and cardiovascular diseases, etc.
\end{abstract}

Keywords: Biofield energy; The Trivedi Effect ${ }^{\circledR}$; Thermogenesis; Mitochondrial biogenesis; Metabolic disorders; Murine myoblast cell; DMEM

Abbreviations: CAM: Complementary and Alternative Medicine, NCCAM: National Center for Complementary and Alternative Medicine; DMEM: Dulbecco's Modified Eagle's Medium; FBS: Fetal Bovine Serum

\section{Introduction}

Mitochondria (also known as power generator of the cell) produce most of the vital energy required for the cellular function through oxidative phosphorylation involved in electron transport and ATP synthesis. They produce ATP through the process of cellular respiration mainly aerobic respiration, which requires oxygen. Number and amount of mitochondria in a cell be governed by the energy requirement of the cell [1]. For example, the muscle cells have found comparatively more number of mitochondria since, they need to produce energy to move the body. On the other hand, red blood cells carry oxygen to other cells, do not need to produce energy as compared with the muscle cells. Mitochondria are the powerhouse in the cell, which produce energy from basic components. They undergo fusion, fission, transport, and degradation, all of the process is vital to maintain a healthy mitochondrial population [1]. However, the mitochondrial biogenesis process is involved an increased and controlled mitochondrial mass with number that helped to produce greater production of ATP as a response to greater energy expenditure [2]. Physiologic, metabolic, and pathologic changes along with morphological and functional adaptability are the vital factor to regulate the process of mitochondrial biogenesis. In addition, proteins and transcription factors, upstream regulatory proteins and secondary mechanisms are also involved in the biogenesis process, which also stabilizes the new mitochondrial DNA [3].

Mitochondrial biogenesis regulates and control various therapeutic interference in wide number of diseases such as metabolic syndrome, neurodegenerative disorders, sarcopenia, cardiac pathophysiology and physiological processes like aging [4]. Nonyl-acridine orange (NAO) is a non-fluorescent dye that converts into fluorescent dye in the presence of oxidative species 
[5]. NAO assay is one of the gold standard assays to detect the mitochondrial mass alteration, which is a metachromatic dye that binds to cardiolipin, an inner mitochondrial membrane lipid, regardless of the energetic state of the cell. Therefore, mitochondrial mass of the cells could be estimated by studying accumulation of the fluorescent dye in the mitochondria. Furthermore, an alternative therapies such as nuclear gene was reported to regulate total mitochondrial mass in response to mitochondrial dysfunction [6]. In order to improve the mitochondrial mass content via thermogenesis process, some alternative treatment approach without any associated side-effect is needed.

Biofield Energy Healing is a categorized as one of the Complementary and Alternative Medicine (CAM) accepted worldwide for the various treatment. Biofield Energy Therapy was accepted by National Center for Complementary and Alternative Medicine (NCCAM). Biofield Energy Healing is one of the emerging frontier in medicine, which has been increased in order to promote wellness by uncovering the root cause of diseases with universal solutions. CAM therapies have shown various significant clinical benefits. Over the past few decades, many energy healing practices have been reported a significant outcomes in various clinical and non-clinical fields. The effects of the CAM therapies have great potential, which include external qigong, Johrei, Reiki, therapeutic touch, yoga, Qi Gong, polarity therapy, Tai Chi, pranic healing, deep breathing, chiropractic/osteopathic manipulation, guided imagery, meditation, massage, homeopathy, hypnotherapy, progressive relaxation, acupressure, acupuncture, special diets, relaxation techniques, Rolfing structural integration, healing touch, movement therapy, pilates, mindfulness, Ayurvedic medicine, traditional Chinese herbs and medicines in biological systems both in vitro and in vivo [7]. Every living organisms possess some kind of unique energy known as Biofield Energy, which is infinite, para-dimensional and electromagnetic field surrounding the human body. Biofield (Putative Energy Fields) based Energy Healing Therapies have been reported to have significant outcomes against various disease conditions. Biofield Energy Healing Treatment (The Trivedi Effect ${ }^{\circledR}$ ) contain a putative bioenergy, which is channeled by a renowned practitioner from a distance. Biofield Energy Healing as a CAM showed a significant results in biological studies [8]. However, the National Center for Complementary and Alternative Medicine (NCCAM), well-defined Biofield Therapies in the subcategory of Energy Therapies [9]. The Trivedi Effect ${ }^{\circledR}$ - Consciousness Energy Healing Treatment has been reported with significant revolution in the physicochemical properties of metals, chemicals, ceramics and polymers [1012], improved agricultural crop yield, productivity, and quality [13,14], transformed antimicrobial characteristics [15-17], biotechnology [18,19], improved bioavailability [20-22], skin health $[23,24]$, nutraceuticals $[25,26]$, cancer research $[27,28]$, bone health [29-31], human health and wellness. On the basis of outstanding benefits of Biofield Energy Treatment, the present study was aimed to evaluate the impact of the Biofield Energy
Treatment (The Trivedi Effect ${ }^{\circledR}$ ) on DMEM as test sample to alter the mitochondrial mass content on thermogenesis using NAO dye staining using standard in vitro assay in murine myoblasts (C2C12) cells.

\section{Material and Methods}

\section{Chemicals and reagents}

Fetal bovine serum (FBS) and Dulbecco's Modified Eagle's Medium (DMEM) were purchased from Life Technology, USA. Antibiotics solution (penicillin-streptomycin) were procured from HiMedia, India, and ethylenediaminetetraacetic acid (EDTA) was purchased from Sigma, USA. All the other chemicals used in this experiment were analytical grade procured from India.

\section{Cell culture}

C2C12 (murine myoblasts) was used as a test system in the present study. The $\mathrm{C} 2 \mathrm{C} 12$ cell line was maintained in DMEM growth medium for routine culture supplemented with 10\% FBS. Growth conditions were maintained at $37^{\circ} \mathrm{C}, 5 \% \mathrm{CO}_{2}$, and $95 \%$ humidity and subcultured by trypsinisation followed by splitting the cell suspension into fresh flasks and supplementing with fresh cell growth medium. Before initiation of the experiment, cells were incubated in DMEM+2\% horse serum (HS) for 3 days to allow the cells to differentiate into myotubes.

\section{Experimental design}

The experimental groups consisted of group 1 (G-I) with untreated DMEM and group 2 (G-II) included the Biofield Energy Treated DMEM.

\section{Consciousness energy healing treatment strategies}

The test item, DMEM was divided into two parts. One part of the test item was treated with the Biofield Energy by a renowned Biofield Energy Healer, Dahryn Trivedi remotely for $\sim 5$ minutes and coded as the Biofield Energy Treated DMEM, while the second part did not receive any sort of treatment and denoted as the untreated DMEM group. Biofield Energy Healer was located in the USA, while the test items were located in the research laboratory of Dabur Research Foundation, New Delhi, India. This Biofield Energy Treatment was administered through Healer's unique Energy Transmission process to the test sample under laboratory conditions. Dahryn Trivedi in this study never visited the laboratory in person, nor had any contact with the test item (DMEM). Further, the untreated DMEM group was treated with a "sham" healer for comparative purposes. The "sham" healer did not have any knowledge about the Biofield Energy Treatment. After that, the Biofield Energy Treated and untreated samples were kept in similar sealed conditions for experimental study.

\section{Assessment of cell viability using MTT assay}

The cell viability was performed by MTT assay in C2C12 cell line. The cells were counted and plated in 96-well plates at the density corresponding to $10 \times 10^{3}$ cells/well/180 $\mu \mathrm{L}$ of cell 
growth medium (DMEM+2\% HS). The above cells were incubated overnight under growth conditions and allowed the cell recovery and exponential growth, which were subjected to serum stripping or starvation. The cells were treated with the Untreated and Biofield Energy Treated test item. The cells in the above plate(s) were incubated for 24 to 72 hours in a $\mathrm{CO}_{2}$ incubator at $37^{\circ} \mathrm{C}, 5 \%$ $\mathrm{CO}_{2}$, and $95 \%$ humidity. Following incubation, the plates were taken out and $20 \mu \mathrm{L}$ of $5 \mathrm{mg} / \mathrm{mL}$ of MTT solution were added to all the wells followed by additional incubation for 3 hours at $37^{\circ} \mathrm{C}$. The supernatant was aspirated and $150 \mu \mathrm{L}$ of DMSO was added to each well to dissolve formazan crystals. The absorbance of each well was read at 540nm using Synergy HT microplate reader, Bio Tek, USA [29]. The percentage cytotoxicity at each tested concentrations of the test items were calculated using the following equation (1):

$$
\% \text { cytotoxicity }=(1-X / R) * 100 \text {. }
$$

Where, $\mathrm{X}=$ Absorbance of the Biofield Treated cells; $\mathrm{R}=$ Absorbance of untreated cells

The percentage cell viability corresponding to each treatment was obtained using the following equation (2):

$$
\% \text { Cell Viability }=(100-\% \text { Cytotoxicity })
$$

The concentrations exhibiting $\geq 70 \%$ cell viability was considered as non-cytotoxic.

\section{Assessment of mitochondrial content}

For the assessment of mitochondrial mass, the cells were counted using an hemocytometer and plated at 4500 cells/well in dark walled 96-well plates in DMEM supplemented with $2 \%$ HS. The cells were incubated overnight under standard growth conditions to allow the cell recovery and exponential growth, which were treated by the test items in different groups followed by incubation with the test items for 72 hours. After incubation with the test items, mitochondrial content was determined by 10 -N-nonyl acridine orange (NAO) dye. 50nM dye was added to each well and the cells were incubated for 30 minutes at $37^{\circ} \mathrm{C}$ and $5 \% \mathrm{CO}_{2}$. After 30 minutes of incubation, media was discarded and cells were washed with phosphate buffer saline (PBS). $150 \mu \mathrm{L}$ of PBS was added to each well and fluorescence was read at 485/20 excitation, 528/20 emission filter using synergy HT microplate reader. The percentage increase in mitochondrial content was calculated using following equation

$\%$ increase $=\left[\right.$ Average $\mathrm{FU}_{\text {Treated }}-$ Average $\left.F U_{\text {Untreated }}\right] * 100 /$ Average $\mathrm{FU}_{L}$

Where, FU denotes Fluorescence unit

\section{Statistical analysis}

All the values were represented as Mean \pm SEM (standard error of mean) of three independent experiments. The statistical analysis was performed using Sigma Plot statistical software (v11.0). For two groups comparison student's t-test was used. Statistically significant values were set at the level of $p \leq 0.05$.

\section{Results and Discussion}

\section{Cell viability using MTT assay}

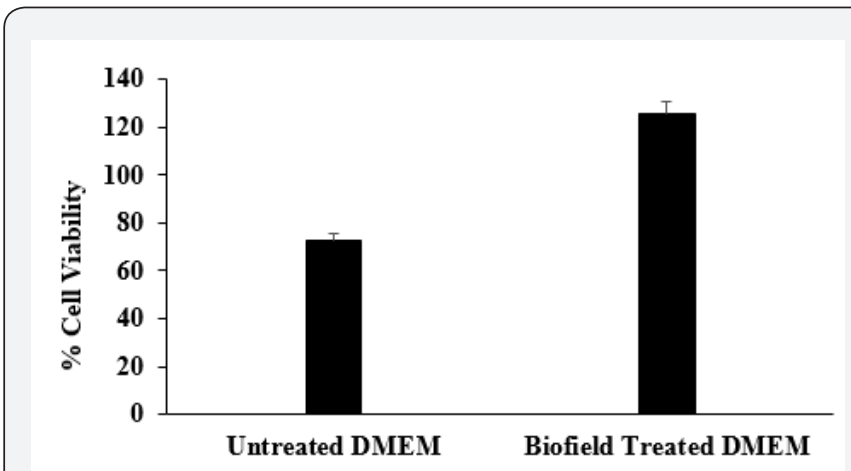

Figure 1: Cell viability using MTT assay of the test items on murine myoblasts (C2C12) cell-line.

Cell viability data of the untreated and Biofield Energy Treated DMEM groups in C2C12 cells using MTT assay is shown in Figure 1 . The percentage of cell viability in the untreated DMEM group was $72.32 \%$, while it was $125.32 \%$ in the Biofield Energy Treated DMEM group (Figure 1). Overall, data suggest that all the test samples were found safe against the tested C2C12 cells, which were used for the estimation of mitochondrial mass content, which indicate extend of thermogenesis.

\section{Extend of mitochondrial mass content in $\mathrm{C} 2 \mathrm{C} 12$ cells}

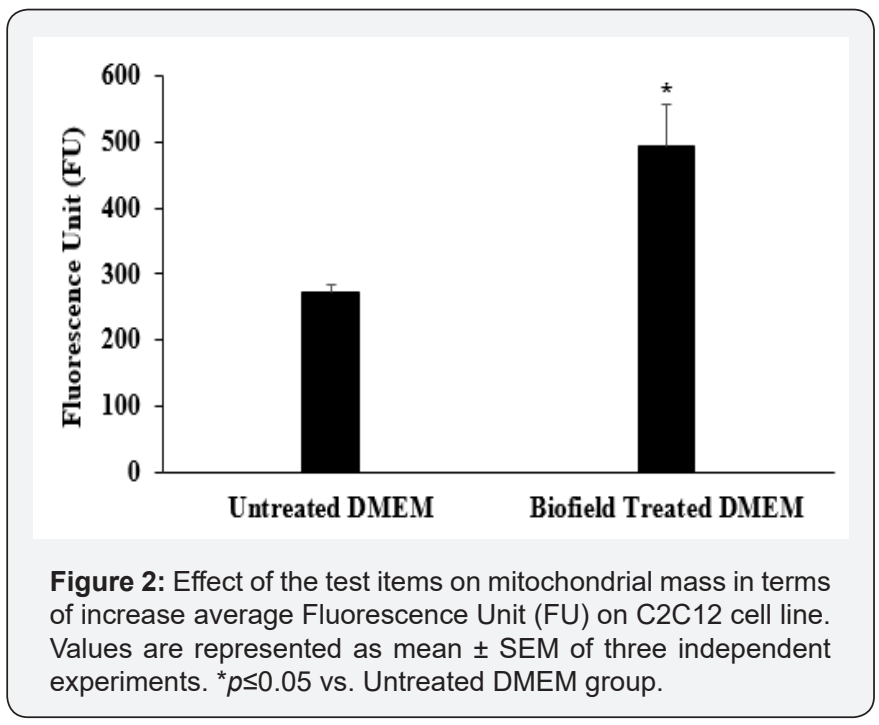

Mitochondrial mass content or biogenesis showed a significant effects against various metabolic diseases. The increased cell capacity to control and maintain the cell metabolism, signal transduction, and regulation of mitochondrial ROS production [2]. Alteration or decrease in the mitochondrial biogenesis are related with the mitochondrial dysfunction and mitochondrial oxidative stress, which leads to various diseases [32]. Mitochondrial mass content results in the improved production of ATP as a response to greater energy expenditure [33]. Various factors such as physical exercise, nutritional factors, etc. reported to have an improved mitochondrial mass content, which results in greater glucose 
uptake by muscles, along with an increased metabolic enzymes level for glycolysis, oxidative phosphorylation and ultimately a greater mitochondrial metabolic capacity [34]. Aging process leads to decrease level of mitochondrial mass content and results in various diseases such as enhanced aging, insulin resistance, type-2 diabetes, cardiovascular diseases, obesity, etc. [35]. The experiment was conducted to study the influence of Biofield Energy Healing Treatment on mitochondrial content in C2C12 cells using NAO dye assay. The results of mitochondrial mass content in terms of increase number of fluorescence unit (FU) among different groups in $\mathrm{C} 2 \mathrm{C} 12$ cells using NAO dye assay are presented in Figure 2. The untreated DMEM group showed 272.3 \pm 12.14 FU. Besides, the Biofield Energy Treated DMEM group showed $81.78 \%$ increase the level of mitochondrial mass in terms of FU, compared to the untreated DMEM group (Figure 2).

Thus, the data suggested that the Consciousness Energy Blessed DMEM showed a significant improvement of thermogenesis, which results in mitochondrial mass content. This phenomenon can be significantly used against various metabolic diseases, such as insulin resistance, type 2 diabetes, and cardiovascular diseases. Overall, the Biofield Energy Healing Treatment (The Trivedi Effect ${ }^{\circledR}$ ) has the significant capacity to improve the overall Quality of life with an improved thermogenesis and mitochondrial content.

\section{Conclusion}

MTT data showed a significant cell viability with ranges from $72.32 \%$ to $125.32 \%$ in different test item groups, which indicated that the test items were safe and non-toxic in nature. Correspondingly, The Trivedi Effect $^{\circledR}$ showed a significant change in mitochondrial mass among different groups. The Biofield Energy Treated DMEM group demonstrated significant increase in the mitochondrial mass by $81.78 \%$ as compared to the untreated DMEM group. Thus, Biofield Energy Healing based DMEM can be significantly used to improve the energy level, endurance, body energy, which can be utilized against many diseases such aging, diabetes, cancer, depression, hypertension, cardiovascular disease, aging, and physical strength. The Biofield Energy Treated (The Trivedi Effect ${ }^{\circledR}$ ) DMEM were found to have a significant impact on thermogenesis, which might significantly improve the mitochondrial content in muscle cells. Therefore, the Consciousness Energy Healing based DMEM might be a suitable alternative media for cell growth. It can be useful for the management of various disorders such as Lupus, Systemic Lupus Erythematosus, Fibromyalgia, Addison Disease, Hashimoto Thyroiditis, Celiac Disease (gluten-sensitive enteropathy), Multiple Sclerosis, Dermatomyositis, Graves' Disease, Myasthenia Gravis, Pernicious Anemia, Aplastic Anemia, Scleroderma, Psoriasis, Rheumatoid Arthritis, Reactive Arthritis, Diabetes, Sjogren Syndrome, Crohn's Disease, Vasculitis, Vitiligo, Chronic Fatigue Syndrome and Alopecia Areata, as well as inflammatory disorders such as Irritable Bowel Syndrome (IBS), Asthma, Ulcerative Colitis, Alzheimer's Disease, Parkinson's Disease, Atherosclerosis,
Dermatitis, Hepatitis, and Diverticulitis. Further, the Biofield Energy Healing Treatment can also be used in the prevention of immune-mediated tissue damage in cases of organ transplants (for example heart transplants, kidney transplants and liver transplants), for anti-aging, stress prevention and management, and in the improvement of overall health and Quality of Life.

\section{Acknowledgements}

Authors are grateful to Dabur Research Foundation, Trivedi Global, Inc., Trivedi Science, Trivedi Testimonials, and Trivedi Master Wellness for their support throughout the work.

\section{Conflict of Interest}

Authors declare no conflict of action.

\section{References}

1. Mishra P, Chan DC (2016) Metabolic regulation of mitochondrial dynamics. J Cell Biol 212(4): 379-387.

2. Jornayvaz FR, Shulman GI (2010) Regulation of mitochondrial biogenesis. Essays Biochem 47: 69-84.

3. Chan DC (2006) Mitochondria: dynamic organelles in disease, aging, and development. Cell 125(7): 1241-1252.

4. Baker MJ, Frazier AE, Gulbis JM, Ryan MT (2007) Mitochondrial protein-import machinery: correlating structure with function. Trends Cell Biol 17(9): 456-464.

5. Cantó C, Pich S, Paz JC, Sanches R, Martínez V, et al. (2007) Neuregulins increase mitochondrial oxidative capacity and insulin sensitivity in skeletal muscle cells. Diabetes 56(9): 2185-2193.

6. Nakashima Kamimura N, Asoh S, Ishibashi Y, Mukai Y, Shidara Y, et al. (2005) MIDAS/GPP34, a nuclear gene product, regulates total mitochondrial mass in response to mitochondrial dysfunction. J Cell Sci 118(Pt 22): 5357-5367.

7. Rubik B (2002) The biofield hypothesis: Its biophysical basis and role in medicine. J Altern Complement Med 8(6): 703-717.

8. Barnes PM, Bloom B, Nahin RL (2008) Complementary and alternative medicine use among adults and children: United States, 2007. Natl Health Stat Report 12: 1-23.

9. Frass M, Strassl RP, Friehs H, Müllner M, Kundi M, et al. (2012) Use and acceptance of complementary and alternative medicine among the general population and medical personnel: A systematic review. Ochsner J 12(1): 45-56.

10. Trivedi MK, Tallapragada RM (2008) A transcendental to changing metal powder characteristics. Met Powder Rep 63(9): 22-28, 31.

11. Trivedi MK, Nayak G, Patil S, Tallapragada RM, Latiyal O (2015) Studies of the atomic and crystalline characteristics of ceramic oxide nano powders after bio field treatment. Ind Eng Manage 4: 161.

12. Trivedi MK, Nayak G, Patil S, Tallapragada RM, Latiyal O, et al. (2015) Effect of biofield energy treatment on physical and structural properties of calcium carbide and praseodymium oxide. International Journal of Materials Science and Applications 4: 390-395.

13. Trivedi MK, Branton A, Trivedi D, Nayak G, Mondal SC, et al. (2015) Morphological characterization, quality, yield and DNA fingerprinting of biofield energy treated alphonso mango (Mangifera indica L) Journal of Food and Nutrition Sciences 3: 245-250.

14. Trivedi MK, Branton A, Trivedi D, Nayak G, Mondal SC, et al. (2015) Evaluation of biochemical marker- Glutathione and DNA fingerprinting of biofield energy treated Oryza sativa. American Journal of Bioscience $3: 243-248$. 
15. Trivedi MK, Branton A, Trivedi D, Nayak G, Charan S, et al. (2015) Phenotyping and $16 \mathrm{~S}$ rDNA analysis after biofield treatment on Citrobacter braakii: A urinary pathogen. J Clin Med Genom 3(6): 129.

16. Trivedi MK, Patil S, Shettigar H, Mondal SC, Jana S (2015) Evaluation of biofield modality on viral load of Hepatitis B and C viruses. J Antivir Antiretrovir 7: 83-88

17. Trivedi MK, Patil S, Shettigar H, Mondal SC, Jana S (2015) An impact of biofield treatment: Antimycobacterial susceptibility potential using BACTEC 460/MGIT-TB System. Mycobact Dis 5(4): 189.

18. Trivedi MK, Patil S, Shettigar H, Bairwa K, Jana S (2015) Phenotypic and biotypic characterization of Klebsiella oxytoca: An impact of biofield treatment. J Microb Biochem Technol 7(4): 203-206.

19. Nayak G, Altekar N (2015) Effect of biofield treatment on plant growth and adaptation. J Environ Health Sci 1(2): 1-9.

20. Branton A, Jana S (2017) The influence of energy of consciousness healing treatment on low bioavailable resveratrol in male Sprague Dawley rats. International Journal of Clinical and Developmental Anatomy 3: 9-15.

21. Branton A, Jana S (2017) The use of novel and unique biofield energy healing treatment for the improvement of poorly bioavailable compound, berberine in male Sprague Dawley rats. American Journal of Clinical and Experimental Medicine 5: 138-144.

22. Branton A, Jana S (2017) Effect of the biofield energy healing treatment on the pharmacokinetics of 25-hydroxyvitamin D3 $\left[25(\mathrm{OH}) \mathrm{D}_{3}\right]$ in rats after a single oral dose of vitamin D3. American Journal of Pharmacology and Phytotherapy 2(1): 11-18.

23. Kinney JP, Trivedi MK, Branton A, Trivedi D, Nayak G, et al. (2017) Overall skin health potential of the biofield energy healing based herbomineral formulation using various skin parameters. American Journal of Life Sciences 5: 65-74.

24. Singh J, Trivedi MK, Branton A, Trivedi D, Nayak G, et al. (2017) Consciousness energy healing treatment based herbomineral formulation: A safe and effective approach for skin health. American Journal of Pharmacology and Phytotherapy 2: 1-10.

25. Trivedi MK, Branton A, Trivedi D, Nayak G, Plikerd WD, et al. (2017) A Systematic study of the biofield energy healing treatment on physico-

This work is licensed under Creative Commons Attribution 4.0 License

DOI: 10.19080/IJCSMB.2018.05.555661 chemical, thermal, structural, and behavioral properties of magnesium gluconate. International Journal of Bioorganic Chemistry 2: 135-145.

26. Trivedi MK, Branton A, Trivedi D, Nayak G, Plikerd WD, et al. (2017) Chromatographic and spectroscopic characterization of the consciousness energy healing treated Withania somnifera (ashwagandha) root extract. European Journal of Biophysics 5: 38-47.

27. Trivedi MK, Patil S, Shettigar H, Mondal SC, Jana S (2015) The potential impact of biofield treatment on human brain tumor cells: A time-lapse video microscopy. J Integr Oncol 4(3): 141.

28. Trivedi MK, Patil S, Shettigar H, Gangwar M, Jana S (2015) In vitro evaluation of biofield treatment on cancer biomarkers involved in endometrial and prostate cancer cell lines. J Cancer Sci Ther 7(8): 253-257.

29. Anagnos D, Trivedi K, Branton A, Trivedi D, Nayak G, et al. (2018) Influence of biofield treated vitamin $\mathrm{D}_{3}$ on proliferation, differentiation, and maturation of bone-related parameters in MG-63 cell-line. International Journal of Biomedical Engineering and Clinical Science 4: 6-14.

30. Lee AC, Trivedi K, Branton A, Trivedi D, Nayak G, et al. (2018) The potential benefits of biofield energy treated vitamin $\mathrm{D}_{3}$ on bone mineralization in human bone osteosarcoma cells (MG-63). International Journal of Nutrition and Food Sciences 7(1): 30-38.

31. Stutheit ME, Trivedi K, Branton A, Trivedi D, Nayak G, et al. (2018) Biofield energy treated vitamin $\mathrm{D}_{3}$ : Therapeutic implication on bone health using osteoblasts cells. American Journal of Life Sciences 6: 13-21.

32. Shey Shing S, Dhananjaya NMW (2006) Targeting antioxidants to mitochondria: A new therapeutic direction. Biochimica et Biophysica Acta 1762(2): 256-265.

33. Valero T (2014) Mitochondrial biogenesis: Pharmacological approaches. Curr Pharm Des 20(35): 5507-5509.

34. Sanchis Gomar F, García-Giménez JL, Gómez-Cabrera MC, Pallardó FV (2014) Mitochondrial biogenesis in health and disease. Molecular and therapeutic approaches. Curr Pharm Des 20(35): 5619-5633.

35. Handy DE, Loscalzo J (2012) Redox regulation of mitochondrial function. Antioxid Redox Signal 16(11): 1323-1367.

\section{Your next submission with Juniper Publishers} will reach you the below assets

- Quality Editorial service

- Swift Peer Review

- Reprints availability

- E-prints Service

- Manuscript Podcast for convenient understanding

- Global attainment for your research

- Manuscript accessibility in different formats

( Pdf, E-pub, Full Text, Audio)

- Unceasing customer service

Track the below URL for one-step submission

https://juniperpublishers.com/online-submission.php 